\title{
PENENTUAN PREMI ASURANSI JIWA BERJANGKA 5 TAHUN MENGGUNAKAN MODEL VASICEK DAN MODEL COX-INGERSOLL-ROSS (CIR)
}

\author{
Selfi Artika \\ Program Studi Informatika, Universitas Teknologi Yogyakarta \\ Email: selfiartika@yahoo.com
}

\begin{abstract}
In determining the premium value is influenced by the interest rate. The magnitude of the interest rate is determined by using the rate model of Vasicek and CIR. This research aims to determine the magnitude of interest rate, premium value, and comparisons of premium values of the Vasicek interest rate model and CIR interest rate models. In this research will be conducted calculation of the premium value of life insurance futures 5 years by using interest rate with the first case premium installment payment when the size of constant but different for the two periods and the second case of premium installment when the magnitude increases linearly when the sum insured is $\frac{1}{12}$ The calculation of life insurance premiums generated from the application of Vasicek model and CIR model is no significant difference.
\end{abstract} Keywords: premium value, term life insurance, interest rate, Vasicek model, CIR model

\begin{abstract}
ABSTRAK
Dalam penentuan besaran nilai premi dipengaruhi oleh tingkat suku bunga. Besaran nilai suku bunga ditentukan dengan menggunakan model suku bunga Vasicek dan model suku bunga CIR. Riset ini bertujuan untuk penentuan besaran nilai suku bunga, besaran nilai premi, dan perbandingan besaran nilai premi dari model suku bunga Vasicek dan model suku bunga CIR. Dalam penelitian ini akan dilakukan perhitungan nilai premi asuransi jiwa berjangka 5 tahun dengan menggunakan nilai suku bunga dengan kasus pertama pembayaran cicilan premi saat besaran konstan tapi berbeda untuk dua periode dan kasus kedua cicilan premi saat besaran meningkat secara linear ketika uang pertanggungan dibayarkan di akhir interval $\frac{1}{12}$ tahun. Hasil perhitungan premi asuransi jiwa berjangka yang dihasilkan dari penerapan model Vasicek dan model CIR bernilai positif dan tidak ada perbedaan yang signifikan.
\end{abstract}

Kata kunci: nilai premi, asuransi jiwa berjangka, suku bunga, model Vasicek, model CIR

\section{PENDAHULUAN}

Secara umum asuransi tidak asing bagi masyarakat Indonesia. Asuransi yang sering diikuti seperti asuransi kematian, asuransi kesehatan, asuransi pendidikan, asurasi kendaraan dan beberapa asuransi lainnya. Namun dalam hal ini sebagian peserta asuransi merasa keberatan jika harus mengikuti asuransi tersebut dalam waktu seumur hidup, sehingga adanya pilihan yang ditawarkan oleh perusahaan asuransi dengan mengikuti asuransi dalam jangka waktu tertentu saja sesuai dengan kebutuhan berdasarkan aturan yang telah 
ditetapkan.

Dengan mengikuti asuransi jiwa berjangka, benefit yang akan diberikan selama jangka waktu tertentu saja (sesuai kesepakatan saat awal memulai asuransi). Pada masa perlindungan, benefit akan dibayarkan apabila terjadi suatu kejadian yang tidak terduga. Kelebihan dari asuransi jiwa berjangka bias memilih berapa jangka waktu yang diinginkan sehingga memiliki fleksibilitas dari pihak tertanggung sesuai dengan kebutuhannya.

Selain jangka waktu yang bisa dipilih oleh peserta asuransi, besaran nilai premi yang akan dibayarkan tiap bulan, $\frac{1}{m}$ bulan atau tiap tahun tahun juga menjadi bahan pertimbangan. Nilai premi untuk mengikuti asuransi dalam jangka waktu tertentu akan hilang sia-sia jika tidak diprediksikan sejak awal. Beberapa pertimbangan yang sering dibicarakan oleh calon peserta asuransi seperti pendapatan tiap bulan, usia, pendidikan, kondisi kesehatan, juga kondisi tempat tinggal.

Dalam penelitian ini, akan dilakukan perhitungan premi asuransi jiwa berjangka per 5 tahun menggunakan besaran tingkat bunga dengan model suku bunga. Model suku bunga yang akan digunakan yaitu model suku bunga Vasicek dan model suku bunga Cox-IngersollRoss (CIR).

Bayazit (2004) mengungkapkan "model suku bunga Vasicek adalah model yang memprediksi pergerakan tingkat bunga untuk waktu berikutnya dengan melihat pergerakan tingkat bunga sebelumnya. Model Vasicek mengikuti fenomena mean reverting, yaitu tingkat bunga akan selalu bergerak menuju titik keseimbangan". Sedangkan Cox et al (1985) menyatakan "model CIR menjamin tingkat suku bunga bernilai positif dan memiliki sifat mean reversion atau mempunyai kecenderungan kembali menuju rata-rata" .

"Selain dipengaruhi oleh tingkat suku bunga, besarnya premi juga dipengaruhi oleh cara pembayaran uang pertanggungan yang disepakati dalam polis. Dalam pembayaran uang pertanggungan ada tiga macam pembayaran, yaitu uang pertanggungan dibayar di akhir tahun, pada akhir interval $\frac{1}{m}$ tahun dan segera apabila terjadi klaim" (Bowers et al.1997).

Simulasi dalam penentuan besaran tingkat bunga yang akan digunakan pada riset ini digunakan model suku bunga Vasicek dan model suku bunga Cox-Ingersol-Ross (CIR) . Hasil dari model tersebut untuk menentukan besaran nilai premi pada asuransi jiwa berjangka 5 tahun dengan dua kasus. Kasus pertama pembayaran cicilan premi saat besaran konstan tapi berbeda untuk dua periode dan kasus kedua cicilan premi saat besaran meningkat secara linear. Nilai Premi yang akan ditentukan untuk kasus uang pertanggungan dibayarkan pada akhir interval $\frac{1}{m}$ tahun.

\section{METODOLOGI}

\subsection{Data}

Data yang digunakan dalam riset ini adalah Data suku bunga tahunan Bank Indonesia dari bulan Juni 2013 samapai bulan Juli 2016 dan Tabel Mortalita Indonesia 2011. Model yang digunakan dalam riset ini adalah Model suku bunga Vasicek dan model suku bunga CIR.

\subsection{Penentuan model persamaan aktuaria premi asuransi jiwa berjangka.}

Persamaan umum aktuaria yang akan digunakan sebagai berikut: $\mathrm{E}($ Nilai sekarang premi $)=\mathrm{E}($ Nilai sekarang benefit $)$ 
2.3 Penentuan nilai suku bunga $r(t)$ bulanan dan tahunan menggunakan persamaan model Vasicek dan model CIR

Dengan bantuan software Matlab, hasil suku bunga $r(t)$ selama 60 bulan untuk periode bulanan sebagai berikut:

Tabel 1 Nilai rata-rata suku bunga $r(t)$ untuk periode bulanan (periode 60 bulan) model suku bunga Vasicek

\begin{tabular}{cccccccccc}
\hline$m$ & $r(t)$ & $m$ & $r(t)$ & $m$ & $r(t)$ & $m$ & $r(t)$ & $m$ & $r(t)$ \\
\hline 0 & 0.004868 & & & & & & & & \\
1 & 0.005505 & 13 & 0.007630 & 25 & 0.008507 & 37 & 0.008378 & 49 & 0.008477 \\
2 & 0.005623 & 14 & 0.007913 & 26 & 0.008795 & 38 & 0.008096 & 50 & 0.008969 \\
3 & 0.006317 & 15 & 0.008378 & 27 & 0.009045 & 39 & 0.007852 & 51 & 0.008893 \\
4 & 0.006837 & 16 & 0.008020 & 28 & 0.008780 & 40 & 0.008134 & 52 & 0.008856 \\
5 & 0.006690 & 17 & 0.008439 & 29 & 0.008401 & 41 & 0.008355 & 53 & 0.008424 \\
6 & 0.007361 & 18 & 0.008401 & 30 & 0.008089 & 42 & 0.008005 & 54 & 0.008287 \\
7 & 0.007522 & 19 & 0.008537 & 31 & 0.008462 & 43 & 0.008035 & 55 & 0.008050 \\
8 & 0.007453 & 20 & 0.009301 & 32 & 0.008188 & 44 & 0.009007 & 56 & 0.008012 \\
9 & 0.007315 & 21 & 0.009060 & 33 & 0.007913 & 45 & 0.008841 & 57 & 0.007921 \\
10 & 0.007668 & 22 & 0.008916 & 34 & 0.008401 & 46 & 0.008454 & 58 & 0.007967 \\
11 & 0.007936 & 23 & 0.008522 & 35 & 0.008408 & 47 & 0.008073 & 59 & 0.008507 \\
12 & 0.007622 & 24 & 0.008545 & 36 & 0.008355 & 48 & 0.008712 & 60 & 0.008180 \\
\hline
\end{tabular}

Tabel 2 Nilai rata-rata suku bunga $r(t)$ untuk periode bulanan (periode 60 bulan) model suku bunga CIR

\begin{tabular}{cccccccccc}
\hline$m$ & $r(t)$ & $m$ & $r(t)$ & $m$ & $r(t)$ & $m$ & $r(t)$ & $m$ & $r(t)$ \\
\hline 0 & 0.004868 & & & & & & & & \\
1 & 0.005104 & 13 & 0.006349 & 25 & 0.006558 & 37 & 0.006550 & 49 & 0.006961 \\
2 & 0.005293 & 14 & 0.006434 & 26 & 0.006705 & 38 & 0.006682 & 50 & 0.006821 \\
3 & 0.005732 & 15 & 0.006597 & 27 & 0.006682 & 39 & 0.006574 & 51 & 0.006698 \\
4 & 0.005975 & 16 & 0.006504 & 28 & 0.006713 & 40 & 0.006566 & 52 & 0.006597 \\
5 & 0.006061 & 17 & 0.006597 & 29 & 0.006659 & 41 & 0.006605 & 53 & 0.006643 \\
6 & 0.006099 & 18 & 0.006519 & 30 & 0.006589 & 42 & 0.006550 & 54 & 0.006574 \\
7 & 0.006209 & 19 & 0.006636 & 31 & 0.006612 & 43 & 0.006473 & 55 & 0.006543 \\
8 & 0.006263 & 20 & 0.006535 & 32 & 0.006519 & 44 & 0.006519 & 56 & 0.006752 \\
9 & 0.006488 & 21 & 0.006496 & 33 & 0.006434 & 45 & 0.006543 & 57 & 0.006643 \\
10 & 0.006418 & 22 & 0.006543 & 34 & 0.006411 & 46 & 0.006682 & 58 & 0.006527 \\
11 & 0.006418 & 23 & 0.006667 & 35 & 0.006721 & 47 & 0.006914 & 59 & 0.006558 \\
12 & 0.006418 & 24 & 0.006612 & 36 & 0.006643 & 48 & 0.006860 & 60 & 0.006465 \\
\hline
\end{tabular}

\subsection{Penentuan nilai parameter $c, \theta$, dan $\sigma$}

Penentuan nilai parameter $c, \theta$, dan $\sigma$ akan dicari berdasarkan data suku bunga tahunan Bank Indonesia dari bulan Juni 2013 sampai bulan Juli 2016 (BI 2017). Dalam kasus ini parameter dihasilkan dengan bantuan simulasi program software Matlab. Persamaan yang digunakan untuk mencari nilai parameter dari $c, \theta$, dan $\sigma$ (Mariana 2015) sebagai berikut: 


$$
\begin{gathered}
c=\frac{n^{2}-2 n+1+\sum_{i=1}^{n-1} r_{t+1} \sum_{i=1}^{n-1} \frac{1}{r_{t}}-\sum_{i=1}^{n-1} r_{t} \sum_{i=1}^{n-1} \frac{1}{r_{t}}-(n-1) \sum_{i=1}^{n-1} \frac{r_{t+1}}{r_{t}}}{\left(n^{2}-2 n+1-\sum_{i=1}^{n-1} r_{t} \sum_{i=1}^{n-1} \frac{1}{r_{t}}\right) \Delta t} \\
\theta=\frac{(n-1) \sum_{i-1}^{n-1} r_{t+1}-\sum_{i-1}^{n-1} \frac{r_{t+1}}{r_{t}} \sum_{i-1}^{n-1} r_{t}}{\left(n^{2}-2 n+1+\sum_{i=1}^{n-1} r_{t+1} \sum_{i=1}^{n-1} \frac{1}{r_{t}}-\sum_{i-1}^{n-1} r_{t} \sum_{i=1}^{n-1} \frac{1}{r_{t}}-(n-1) \sum_{i=1}^{n-1} \frac{r_{t+1}}{r_{t}}\right)} \\
\sigma=\sqrt{\frac{1}{n-2} \sum_{i=1}^{n-1}\left(\frac{r_{t+1}-r_{t}}{\sqrt{r_{t}}}-\frac{\theta}{\sqrt{r_{t}}}+c \sqrt{r_{t}}\right)^{2}}
\end{gathered}
$$

\subsection{Penentuan nilai rata-rata suku bunga $r(t)$}

Model suku bunga Vasicek dan model suku bunga CIR akan menghitung nilai rata-rata suku bunga $r(t)$ menggunakan nilai parameter parameter $c, \theta, \sigma$. "Persamaan model suku bunga Vasicek" (Brigo et al.2006) sebagai berikut:

$$
d r(t)=c(\theta-r(t)) d t+\sigma d W(t)
$$

dan "persamaan model suku bunga CIR" (Brigo et al.2006) sebagai berikut:

$$
d r(t)=c(\theta-r(t)) d t+\sigma \sqrt{r(t)} d W(t)
$$

\subsection{Menghitung Nilai Premi}

Besaran nilai suku bunga $r(t)$ akan digunakan pada persamaan model suku bunga Vasicek dan model suku bunga CIR untuk menentukan nilai besaran nilai premi asuransi jiwa berjangka 5 tahun saat pembayaran cicilan premi dengan besaran konstan tapi berbeda untuk dua periode dan pembayaran cicilan premi saat besaran meningkat secara linear saat uang pertanggungan dibayar di akhir interval $\frac{1}{12}$ tahun. Dalam penelitian ini akan digunakan asumsi dengan distribusi seragam.

\section{HASIL DAN PEMBAHASAN}

\subsection{Nilai Parameter}

Penggunaan data observasi berupa rata-rata tingkat suku bunga tahunan Bank Indonesia (BI rate) mengestimasi nilai parameter dari suku bunga model Vasicek dan CIR. Hasil estimasi parameter yang diperoleh akan digunakan untuk menghitung nilai suku bunga model Vasicek dan suku bunga model CIR dan diperoleh data sebagai berikut: $c=2.063$, $\theta=0.0738$ dan $\sigma=0.2891$.

\subsection{Nilai Premi}

Dalam penentuan besaran nilai premi pada kasus pertama diilustrasikan akan dihitung nilai premi asuransi jiwa berjangka 5 tahun, dengan 2 tahun pertama disebut periode 1 dan 3 tahun berikutnya sebagai periode 2 , sedangkan pada kasus kedua yaitu menghitung nilai cicilan premi yang meningkat secara linear juga digunakan asuransi jiwa berjangka waktu 5 tahun, dimana penambahan nilai premi akan meningkat linear setiap tahun selama jangka waktu per 5 tahun. 
Angka harapan hidup ada pada angka 70,1 tahun untuk penduduk Indonesia menurut data sensus BPS 2018, sehingga nilai besaran premi akan dihitung dari usia 0 sampai 70 tahun dalam hitungan per lima tahun untuk setiap tingkatan tahunnya. Penduduk laki-laki dan perempuan yang akan dilakukan perhitunganberdasarkan Tabel Mortalita Penduduk Indonesia tahun 2011.

\subsection{Nilai Cicilan Premi saat Besaran Konstan tapi Berbeda untuk Dua Periode dengan Model Vasicek dan CIR}

Penentuan nilai premi asuransi jiwa berjangka 5 tahun dengan pembayaran cicilan premi saat besaran konstan tapi berbeda untuk dua periode saat benefit dibayarkan di akhir interval $\frac{1}{12}$ tahun dan anuitas premi di awal interval $\frac{1}{12}$ tahun digunakan persamaan berikut:

$$
P=\frac{A_{x: n_{1} \mid}^{1}+2 A_{x+n_{1}}^{(m)} \bar{n}_{1}^{(m)} n_{1} E_{x}}{\ddot{a}_{\chi: n \mid}^{(m)}}
$$

\subsection{Nilai Cicilan Premi saat Besaran Meningkat Secara Linear dengan Model Vasicek dan CIR}

Penentuan nilai premi asuransi jiwa berjangka tahun dengan pembayaran cicilan premi saat besaran meningkat secara linear ketika benefit dibayarkan di akhir interval $\frac{1}{12}$ tahun dan anuitas premi di awal interval $\frac{1}{12}$ tahun digunakan persamaan berikut:

$$
P=\frac{(I A)_{\chi: n \mid}^{1} \overline{a_{x: n \mid}}}{\frac{(m)}{x: n}}
$$

\subsection{Nilai Cicilan Premi saat Besaran Konstan tapi Berbeda untuk Dua Periode dengan Model Vasicek dan CIR}

Dengan menggunakan persamaan (3), nilai sekarang benefit dan nilai premi untuk asuransi jiwa berjangka 5 tahun pada kasus yang pertama dengan pembayaran cicilan premi saat besaran konstan tapi berbeda untuk dua periode ketika benefit dibayarkan di akhir interval $\frac{1}{12}$ tahun dan anuitas preminya di awal interval $\frac{1}{12}$ tahun dengan metode Vasicek dan CIR. Nilai sekarang benefit dan nilai preminya yang dihasilkan dapat dilihat pada Gambar 1 dan Gambar 2. 


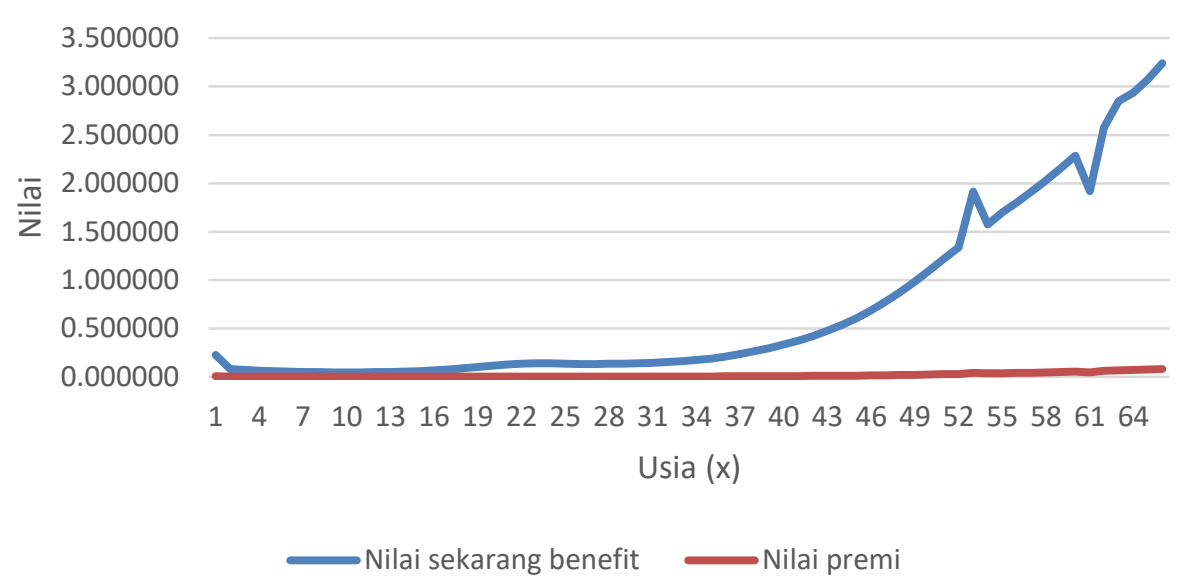

(a) Laki-laki

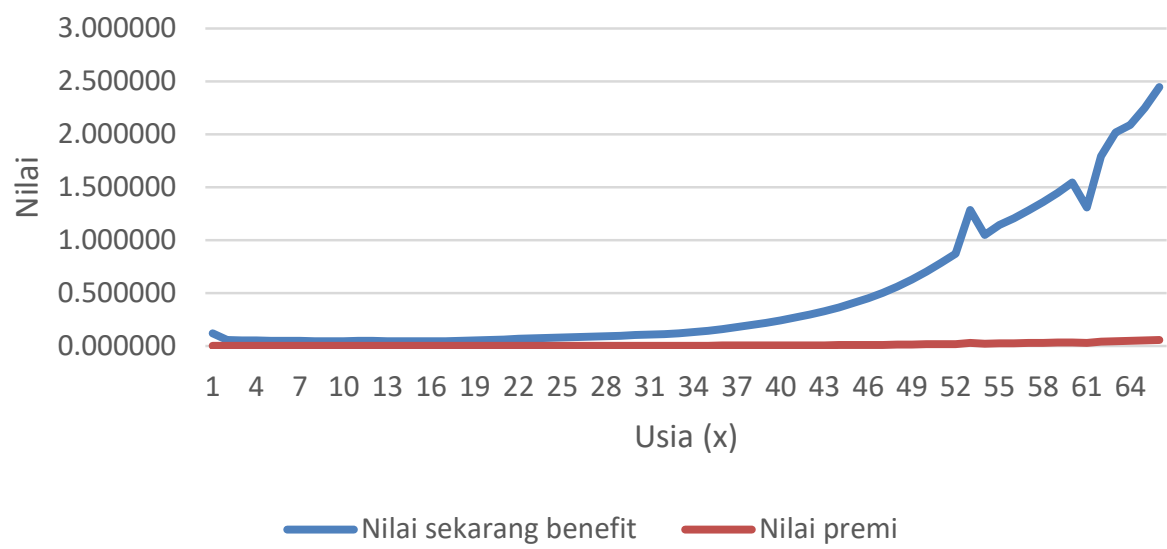

(b) Perempuan

\section{Gambar 1 Nilai cicilan premi saat besaran konstan tapi berbeda untuk dua periode dengan model Vasicek}

Berdasaran grafik pada Gambar 1, maka dapat dijelaskan bahwa:

Pada laki-laki:

a. Nilai sekarang benefit saat usia 0 tahun (baru lahir) sampai usia 10 tahun mengalami penurunan dari 0.224683 menjadi 0.026580 , saat usia 10 tahun sampai 22 tahun mengalami kenaikan dari 0.026580 sampai 0.139486 , saat usia 23 tahun sampai 26 tahun mengalami penururnan dari 0.139486 menjadi 0.132405 , saat usia 26 tahun sampai 59 tahun senantiasa mengalami kenaikan dari 0.132405 sampai 2.285657, turun saat usia 60 tahun menjadi 1.917406, saat usia 60 tahun sampai 65 tahun mengalami kenaikan dari 1.917406 menjadi 3.239388 .

b. Nilai premi saat usia 0 tahun (baru lahir) sampai usia 7 tahun mengalami penurunan dari 0.004801 menjadi 0.001014 , naik saat usia 8 tahun sampai 0.001147 , dan turun usia 10 tahun menjadi 0.000976 , saat usia 10 tahun sampai 65 tahun mengalami kenaikan dari 0.000976 sampai 0.078625 . 
Pada perempuan:

a. Nilai sekarang benefit saat usia 0 tahun (baru lahir) sampai usia 9 tahun mengalami penurunan dari 120622 menjadi 0.045194, saat usia 9 tahun sampai 11 tahun mengalami kenaikan dari 0.045194 sampai 0.047244 , saat usia 11 tahun sampai 15 tahun mengalami penurunan dari 0.047244 menjadi 0.042760 , saat usia 15 tahun sampai 65 tahun senantiasa mengalami kenaikan dari 0.042760 sampai 2.447568 .

b. Nilai premi saat usia 0 tahun (baru lahir) sampai usia 7 tahun mengalami penurunan dari 0.002549 menjadi 0.000962 , naik saat usia 8 tahun sampai 0.001108 , saat usia 8 tahun sampai 15 tahun mengalami penurunan dari 0.001108 menjadi 0.000901 , saat usia 15 tahun sampai usia 65 tahun senantiasa mengalami kenaikan dari 0.000901 sampai 0.056214 .

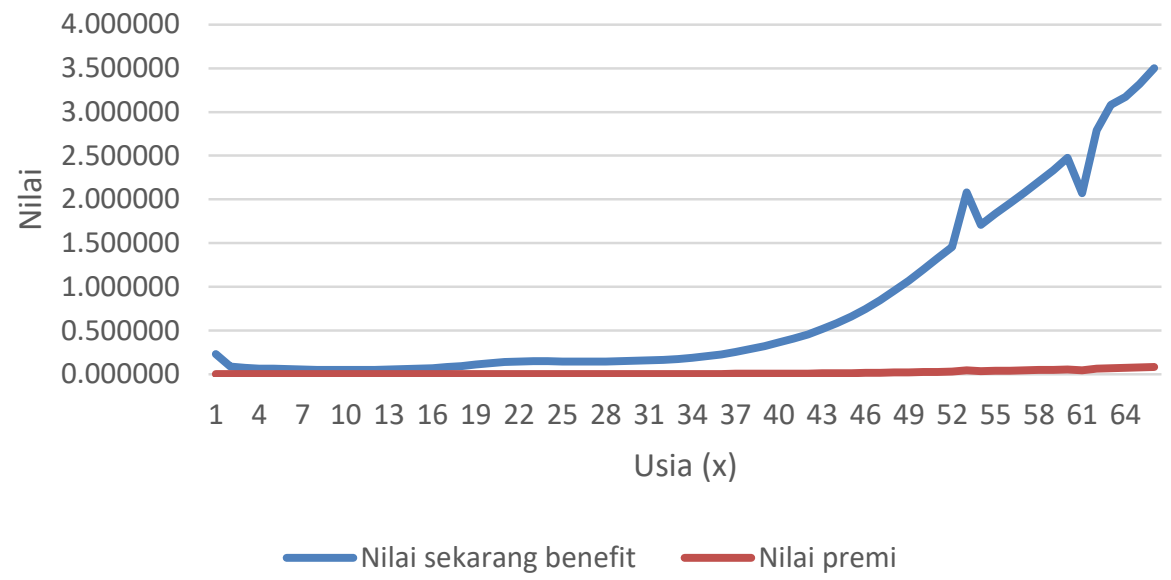

(a) Laki-laki

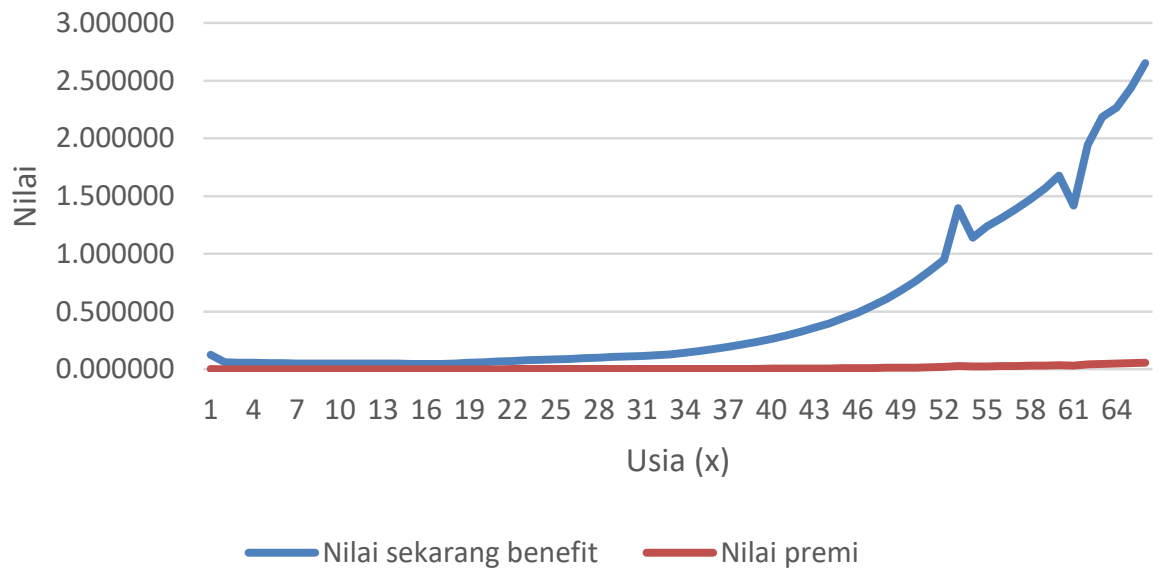

(b) Perempuan

Gambar 2 Nilai cicilan premi saat besaran konstan tapi berbeda untuk dua periode dengan model CIR 
Berdasaran grafik pada Gambar 2, maka dapat dijelaskan bahwa:

Pada laki-laki:

a. Nilai sekarang benefit saat usia 0 tahun (baru lahir) sampai usia 10 tahun mengalami penurunan dari 0.231886 menjadi 0.050543 , saat usia 10 tahun sampai 22 tahun mengalami kenaikan dari 0.050543 sampai 0.151513 , saat usia 22 tahun sampai 26 tahun mengalami penururnan dari 0.151513 menjadi 0.143522 , saat usia 26 tahun sampai 52 tahun senantiasa mengalami kenaikan dari 0.143522 sampai 2.081511, turun kembali saat usia 53 menjadi 1.709469, saat usia 53 tahun sampai 65 tahun mengalami kenaikan sampai 3.498494.

b. Nilai premi saat usia 0 tahun (baru lahir) sampai usia 10 tahun mengalami penurunan dari 0.004760 menjadi 0.001017 , saat usia 10 tahun sampai 22 tahun mengalami kenaikan dari 0.001017 sampai 0.003058 , saat usia 22 tahun sampai 26 tahun mengalami penururnan dari 0.003058 menjadi 0.002904 , saat usia 26 tahun sampai 52 tahun senantiasa mengalami kenaikan dari 0.002904 sampai 0.044383 , turun kembali saat usia 53 menjadi 0.036118, saat usia 53 tahun sampai 65 tahun mengalami kenaikan sampai 0.081923 .

Pada perempuan:

a. Nilai sekarang benefit saat usia 0 tahun (baru lahir) sampai usia 9 tahun mengalami penurunan dari 0.125488 menjadi 0.049009 , saat usia 9 tahun sampai 11 tahun mengalami kenaikan dari 0.049009 sampai 0.051303 , saat usia 11 tahun sampai 15 tahun mengalami penurunan dari 0.051303 menjadi 0.046340 , saat usia 15 tahun sampai 52 tahun senantiasa mengalami kenaikan dari 0.046340 sampai 1.397195 , turun saat usia 53 tahun menjadi 1.139263, saat usia 63 tahun sampai 65 tahun mengalami kenaikan kembali dari 1.139263 sampai 2.653354 .

b. Nilai premi saat usia 0 tahun (baru lahir) sampai usia 9 tahun mengalami penurunan dari 0.002547 menjadi 0.000986 , saat usia 9 tahun sampai 11 tahun mengalami kenaikan dari 0.000986 sampai 0.001033 , saat usia 11 tahun sampai 15 tahun mengalami penurunan dari 0.001033 menjadi 0.000932 , saat usia 15 tahun sampai 52 tahun senantiasa mengalami kenaikan dari 0.000932 sampai 0.029093 , turun saat usia 53 tahun menjadi 0.2023610 , saat usia 53 tahun sampai 65 tahun mengalami kenaikan kembali dari 0.2023610 sampai 0.058690.

\subsection{Nilai Cicilan Premi saat Besaran Meningkat Secara Linear dengan Model Vasicek dan CIR}

Dengan menggunakan persamaan (4), nilai sekarang benefit dan nilai premi untuk asuransi jiwa berjangka 5 tahun untuk kasus yang kedua dengan pembayaran cicilan premi saat besaran meningkat secara linear ketika benefit dibayarkan di akhir interval $\frac{1}{12}$ tahun dan anuitas preminya di awal interval $\frac{1}{12}$ tahun. Perhitungan nilai sekarang benefit dan nilai premi yang dihasilkan dapat dilihat pada Gambar 3 dan Gambar 4. 


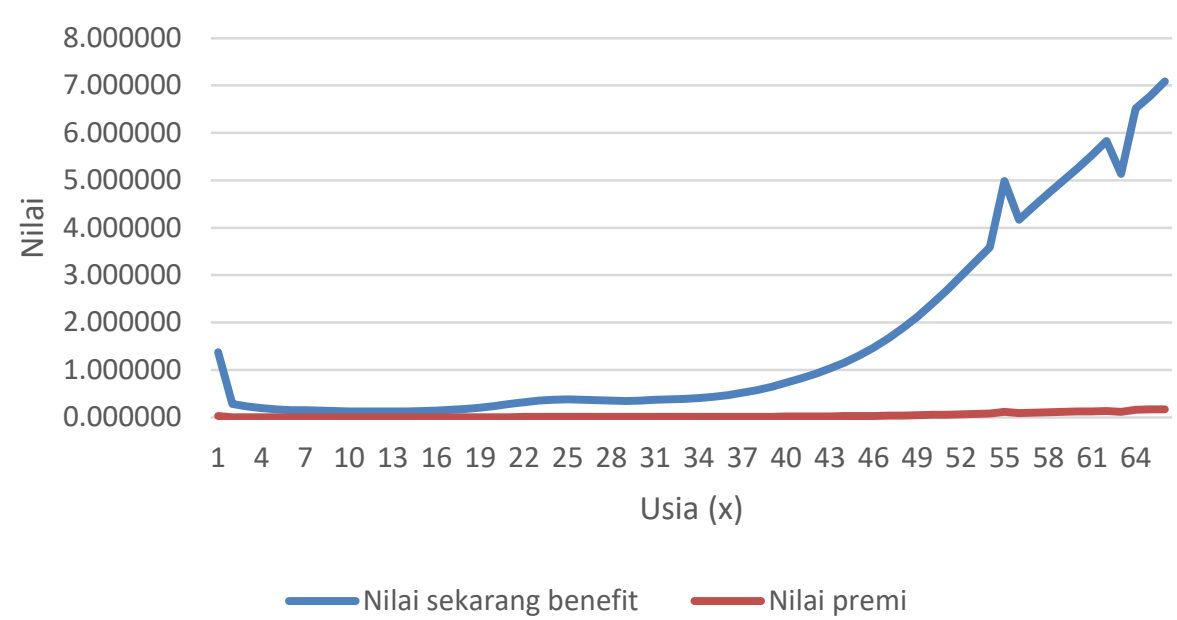

(a) Laki-laki

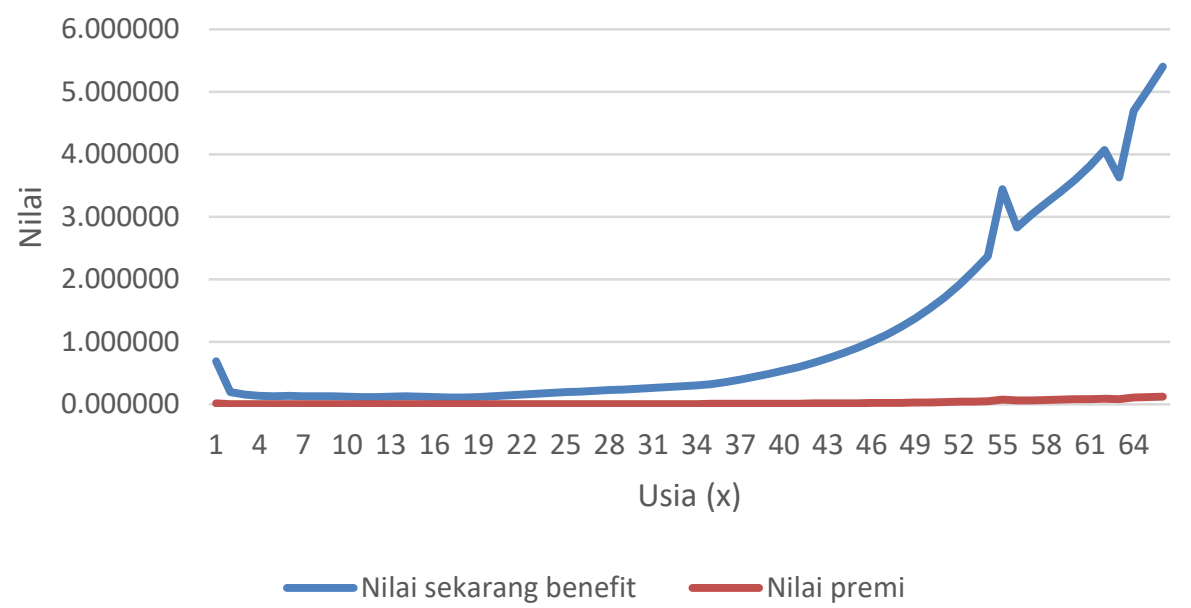

(b) Perempuan

\section{Gambar 3 Nilai cicilan premi saat besaran meningkat secara linear dengan model Vasicek}

Berdasaran grafik pada Gambar 3, maka dapat dijelaskan bahwa:

Pada laki-laki:

a. Nilai sekarang benefit saat usia 0 tahun (baru lahir) sampai usia 10 tahun mengalami penurunan dari 1.373786 menjadi 0.122963 , saat usia 10 tahun sampai 54 tahun senantiasa mengalami kenaikan dari 0.122963 sampai 4.982714 , turun saat usia 55 tahun menjadi 4.168245, saat usia 55 tahun sampai 61 tahun mengalami kenaikan dari 4.168245 sampai 5.826922, turun saat usia 62 tahun menjadi 5.136443, dan saat usia 62 tahun sampai 65 tahun mengalami kenaikan dari 5.136443 sampai 7.088553.

b. Nilai premi saat usia 0 tahun (baru lahir) sampai usia 10 tahun mengalami penurunan dari 0.029354 menjadi 0.002576 , saat usia 10 tahun sampai 54 tahun senantiasa mengalami kenaikan dari 0.002576 sampai 0.113092 , turun saat usia 55 tahun menjadi 0.093673 , saat usia 55 tahun sampai 61 tahun mengalami kenaikan dari 0.093673 sampai 0.137416 , turun saat usia 62 tahun menjadi 0.120153, dan saat usia 62 tahun sampai 65 tahun mengalami kenaikan dari 0.120153 sampai 0.172050 . 
Pada perempuan:

a. Nilai sekarang benefit saat usia 0 tahun (baru lahir) sampai usia 10 tahun mengalami penurunan dari 0.689330 menjadi 0.117940 , saat usia 10 tahun sampai 54 tahun senantiasa mengalami kenaikan dari 0.117940 sampai 3.439878, turun saat usia 55 tahun menjadi 2.829267, saat usia 55 tahun sampai 61 tahun mengalami kenaikan dari 2.829267 sampai 4.067643, turun saat usia 62 tahun menjadi 3.626538, dan saat usia 62 tahun sampai 65 tahun mengalami kenaikan dari 3.626538 sampai 5.398925.

b. Nilai premi saat usia 0 tahun (baru lahir) sampai usia 10 tahun mengalami penurunan dari 0.014566 menjadi 0.002470 , saat usia 10 tahun sampai 54 tahun senantiasa mengalami kenaikan dari 0.002470 sampai 0.075725 , turun saat usia 55 tahun menjadi 0.061893 , saat usia 55 tahun sampai 61 tahun mengalami kenaikan dari 0.061893 sampai 0.091540, turun saat usia 62 tahun menjadi 0.081371 , dan saat usia 62 tahun sampai 65 tahun mengalami kenaikan dari 0.081371 sampai 0.123998 .

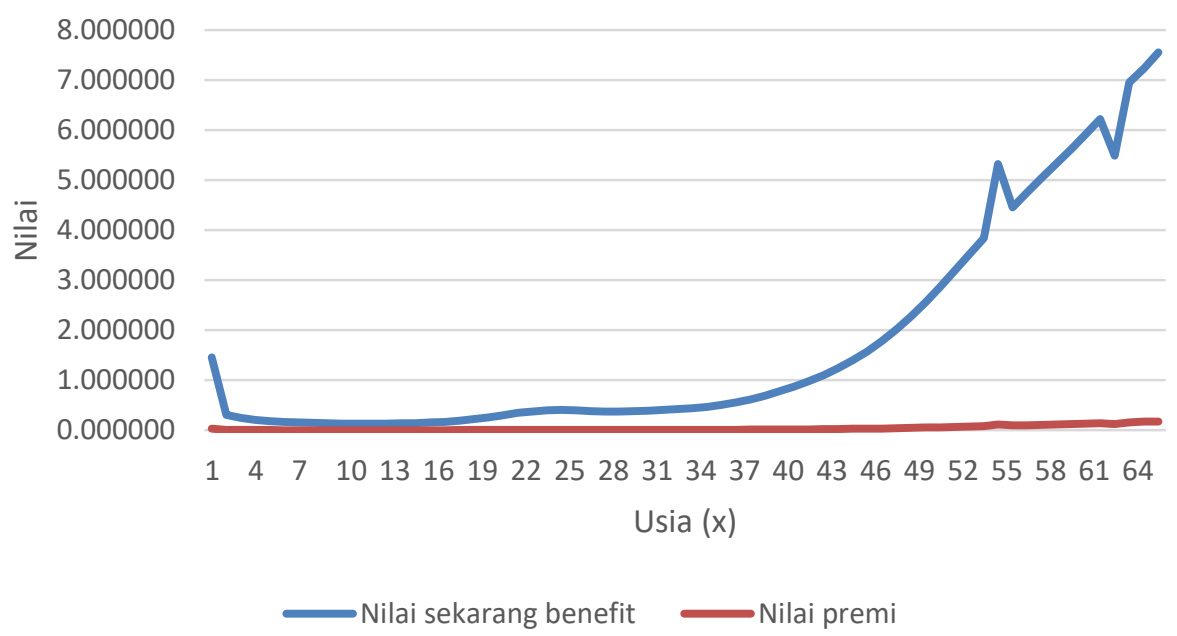

(a) Laki-laki

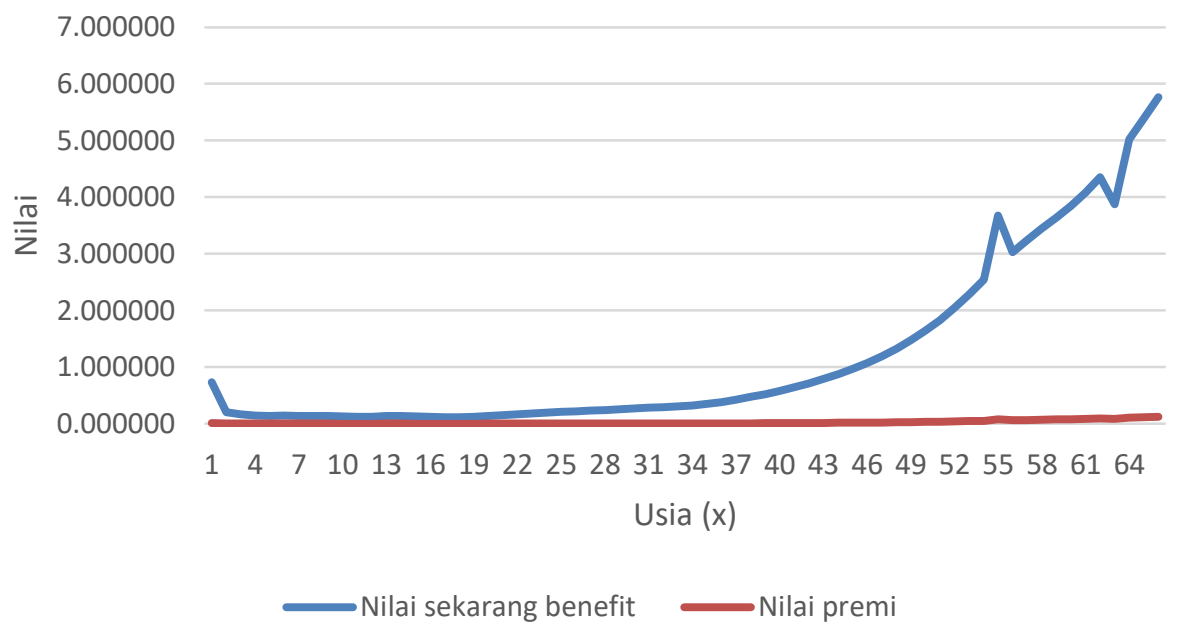

(b) Perempuan

Gambar 4 Nilai cicilan premi saat besaran meningkat secara linear dengan model CIR 
Berdasaran grafik pada Gambar 4, maka dapat dijelaskan bahwa:

Pada laki-laki:

a. Nilai sekarang benefit saat usia 0 tahun (baru lahir) sampai usia 10 tahun mengalami penurunan dari 1.457209 menjadi 0.131617 , saat usia 10 tahun sampai 54 tahun senantiasa mengalami kenaikan dari 0.131617 sampai 5.323566, turun saat usia 55 tahun menjadi 4.457045 , saat usia 55 tahun sampai 61 tahun mengalami kenaikan dari 4.457045 sampai 6.220802, turun saat usia 62 tahun menjadi 5.483540, dan saat usia 62 tahun sampai 65 tahun mengalami kenaikan dari 5.483540 sampai 7.552413.

b. Nilai premi saat usia 0 tahun (baru lahir) sampai 7 tahun mengalami penurunan dari 0.014855 menjadi 0.002838 , naik saat usia 8 tahun sampai 0.003177 , menurun saat usia 10 tahun menjadi 0.002541 , saat usia 10 tahun sampai 54 tahun senantiasa meningkat dari 0.002541 sampai 0.077890 , turun kembali saat usia 55 tahun menjadi 0.063695 , saat usia 55 tahun sampai 61 tahun meningkat dari 0.063695 sampai 0.094228 , turun kembali saat usia 62 tahun menjadi 0.083681, dan saat usia 65 tahun sampai 70 tahun mengalami kenaikan dari 0.083681 sampai 0.127573 .

Pada perempuan:

a. Nilai sekarang benefit saat usia 0 tahun (baru lahir) sampai usia 4 tahun mengalami penurunan dari 0.731864 menjadi 0.141610 , naik saat usia 5 tahun sampai 0.144002 , saat usia 5 tahun sampai 10 tahun mengalami penurunan dari 0.144002 menjadi 0.126317 , saat usia 10 tahun sampai usia 61 tahun mengalami kenaikan dari 0.126317 sampai 4.350078, turun saat usia 62 tahun menjadi 3.875447, dan saat usia 62 tahun sampai 65 tahun mengalami kenaikan dari 3.875447 sampai 5.767470.

b. Nilai premi saat usia 0 tahun (baru lahir) sampai 7 tahun mengalami penurunan dari 0.014855 menjadi 0.002838 , naik saat usia 8 tahun sampai 0.003177 , menurun saat usia 10 tahun menjadi 0.002541 , saat usia 10 tahun sampai 54 tahun senantiasa meningkat dari 0.002541 sampai 0.077890 , turun kembali saat usia 55 tahun menjadi 0.063695 , saat usia 55 tahun sampai 61 tahun meningkat dari 0.063695 sampai 0.094228 , turun kembali saat usia 62 tahun menjadi 0.083681 , dan saat usia 65 tahun sampai 70 tahun mengalami kenaikan dari 0.083681 sampai 0.127573 .

\section{SIMPULAN}

Penentuan besaran tingkat bunga dalam menghitung nilai premi asuransi iwa berjangka 5 tahun berhasil diterapkan dengan menggunakan model suku bunga Vasicek dan model suku Bungan CIR. Dalam peneltian ini, secara keseluruhan besaran nilai premi asuransi jiwa berjangka 5 tahun bernilai positif, baik pada kasus cicilan premi saat besaran konstan tapi berbeda untuk dua periode maupun pada kasus ketika cicilan premi saat besaran meningkat secara linear. Hasil perhitungan besaran nilai premi asuransi jiwa berjangka 5 tahun menghasilkan angka yang tidak berjauhan baik nilai sekarang benefit maupun anuitasnya dengan tingkat ketelitian enam angka di belakang koma sehingga tidak ada perbedaan yang signifikan. Rata-rata yang dihasilkan dari perbandingan nilai sekarang benefit 50 kali lebih besar daripada nilai preminya. 


\section{DAFTAR PUSTAKA}

Bayazit D. 2004. Yiel Curve Estimation and Prediction with Vasicek Model. The Midle East Technical University, Ankara.

Bowers NL, Gerber HU, Hickman JC, Jones DA, Nesbitt CJ. 1997. Actuarial Mathematics. The Society of Actuaries, United States of America.

[BI] Bank Indonesia. 2017. BI 7-day (Reverse) Repo Rate [Internet]. [diunduh 2017 Maret 14]. Tersedia pada: $\underline{\text { https://www.bi.go.id/id/moneter/bi-7day- }}$ RR/data/Contents/Default.aspx

[BPS] Badan Pusat Statistik. 2018. Angka Harapan Hidup Penduduk Beberapa Negara tahun 1995-2015 [Internet]. [diunduh 2018 April 11]. Tersedia pada: https://www.bps.go.id/statictable/2014/09/22/1517/angka-harapan-hidup-pendudukbeberapa-negara-tahun-1995-2015.html

Brigo D, Mercurio F. 2006. Interest Rate Models -Theory and Practice. Springer-Verlag, Germany.

Cox JC, Ingersoll JE. Ross SA. 1985. A theory of the term structure of interst rate. Econometrica, 53(3): 385-408.

Mariana E, Apriliani E, Surjanto SD. 2015. Estimasi Parameter pada Model Suku Bunga Cox Ingersoll Ross (CIR) Menggunakan Kalman Filter untuk Menentukan Harga Zero Coupon Bond. Jurnal Sains dan Seni ITS. 4:2337-3520. 